\title{
EFFECT OF TWO CHEMOTYPES OF OREGANO ESSENTIAL OIL ON BROILER PERFORMANCE, NUTRIENT BALANCE, AND LIPID PEROXIDATION OF BREAST MEAT DURING STORAGE
}

\section{EFEITO DE DOIS QUIMIOTIPOS DE ÓLEO ESSENCIAL DE ORÉGANO NO DESEMPENHO DO FRANGO, EQUILÍBRIO DE NUTRIENTES E PEROXIDAÇÃO LIPÍDICA DA CARNE DE PEITO DURANTE O ARMAZENAMENTO}

\author{
Claudia Ariza Nieto ${ }^{1}$ \\ Ronnal Esneyder Ortiz ${ }^{*}$ \\ Germán Afanador Tellez ${ }^{2}$ \\ ${ }^{1}$ Corporación Colombiana de Investigación Agropecuaria, Bogotá, COL. \\ ${ }^{2}$ Universidad Nacional de Colombia, Bogotá, COL \\ *Corresponding author: rortiz@corpoica.org.co
}

\begin{abstract}
This study evaluated the functional effects of two chemotypes of oregano essential oil (OEO): Lippia Origanoides (LO) and a comercial product Synergy Essence (SE). Broilers were randomly assigned to one of eight dietary treatments: 1) Basal diet (BD); 2) BD+ antibiotic growth promoters (AGP) (bacitracin 50g/ton); 3) $\mathrm{BD}+\mathrm{LO} 125$ (125g/ton); 4) $\mathrm{BD}+\mathrm{LO} 250$ (250g/ton); 5) $\mathrm{BD}+\mathrm{LO} 500$ (500g/ton); 6) BD+SE125 (125g/ton); 7) BD+SE250 (250g/ton); 8) BD+SE500 (500g/ton). At the time of slaughter $(42 \mathrm{~d})$, five birds per treatment were slaughtered. A portion of the breast was minced and stored at $-4{ }^{\circ} \mathrm{C}$ for 3,6 , and 9 days. Lipid peroxidation was determined by measuring of malondialdehyde (MDA), data were analyzed as a completely randomized design with a factorial arrangement of treatments $(8 \mathrm{x} 4)$. Broilers fed SE250 had greater average daily gain (ADG) compared to broilers fed $\mathrm{BD}(\mathrm{P}<0.05)$. Broilers fed LO500 had greater $(\mathrm{P}<0.05)$ organic matter digestibility than the ones fed BD. As days of storage increased, MDA concentration increased $(\mathrm{P}<0.05)$. Broilers fed SE500 had lower $(\mathrm{P}<0.05)$ MDA concentration than those fed BD and AGP. These data indicate that birds fed OEO grow faster than those fed a BD, similar to birds fed AGP. Some of these responses are possibly explained by increased digestibility and energy utilization. In addition, providing OEO from $\mathrm{SE}$ at $500 \mathrm{~g} /$ ton resulted in lower lipid peroxidation in ground breast meat throughout the tested storage time.
\end{abstract}

Keywords: broiler performance; nutrient balance; oxidative stability.

\section{Resumo}

Este estudo avaliou os efeitos funcionais de dois quimiótipos de óleo esencial de orégano (OEO): Lippia Origanoides (LO) e um produto comercial Synergy Essence (SE). Os frangos de corte foram distribuídos aleatoriamente para um dos oito tratamentos dietéticos: 1) Dieta basal (BD); 2) BD + 
antibiótico promotor de crescimento (AGP) (bacitracina $50 \mathrm{~g} /$ tonelada); 3) BD + LO125 (125 $\mathrm{g} /$ tonelada); 4) BD + LO250 (250 g/tonelada); 5) BD + LO500 (500 g/tonelada); 6) BD + SE125 (125 $\mathrm{g} /$ tonelada); 7) BD + SE250 (250 g/tonelada); 8) BD + SE500 (500g/tonelada). No momento do abate $(42 \mathrm{~d})$, cinco aves por tratamento foram abatidas. Uma porção do peito foi picada e armazenada a $4{ }^{\circ} \mathrm{C}$ durante 3, 6 e 9 dias. A peroxidação lipídica foi determinada pela medição de malondialdeído (MDA), os dados foram analisados como um delineamento inteiramente casualizado com um arranjo fatorial de tratamentos $(8 \mathrm{x} 4)$. Os frangos alimentados com SE250 apresentaram maior ganho diário médio (ADG) em comparação com o $\mathrm{BD}(\mathrm{P}<0,05)$. Os frangos alimentados com LO500 apresentaram maior digestibilidade da matéria orgânica $(\mathrm{P}<0,05)$ do que $\mathrm{BD}$. À medida que o dia do armazenamento aumentou, a concentração de MDA aumentou $(\mathrm{P}<0,05)$ Os frangos de corte alimentados com SE500 apresentaram menor concentração de MDA (BD <0,05) do que BD e AGP. Esses dados indicam que as aves alimentadas com $\mathrm{OEO}$ crescem mais rápido do que aquelas alimentadas com BD e semelhantes às aves alimentadas com AGP, com algumas dessas respostas sendo possivelmente explicadas pelo aumento da digestibilidade e da utilização de energia, além de fornecer OEO do SE a 500g/ton, frangos de corte resulta em menor Peroxidação lipídica na carne de peito moída ao longo do tempo de armazenamento testado.

Palavras-Chave: Desempenho do frango, equilibrio de nutrientes, estabilidade oxidativa

Received on: July 14th, 2017.

Accepted on: May 8th, 2018.

\section{Introduction}

The primary effects associated with the inclusion of antimicrobial feed additives include the prevention of digestive disorders, improved feed utilization, and animal performance. Other effects include reduced nutrient waste, diminished environmental impact and reduced production costs. The use of antibiotic growth promoters (AGP) in broiler feeding systems is a powerful tool in the poultry industry to promote growth; however, it renews controversial positions on a wide range of people due to health concerns related to the possible transfer of antibiotic resistance among pathogenic species. At present, eleven antimicrobial components are listed as growth promoters, five treat coccidiosis and six for other usages. Seven of these compounds, including bacitracin, oxytetracycline, novobiocin, erythromycin, lincomycin, and chlortetracycline are also used in human medicine ${ }^{(1)}$.

The phasing out of AGP is affecting the broiler industry at large. Therefore, in order to minimize performance loss, there is a need to find alternatives to AGP. One alternative is the development of other feed additives that have a positive effect on broiler performance and meat markets. Currently, there are a number of non-therapeutic alternatives such as probiotics, prebiotics, enzymes, inorganic acids, immunostimulants, and essential oils, such as oregano essential oils (OEO). Oregano is the common name used for several genera of Origanum and Lippia from the Lamiaceae and Verbenaceae family, respectively.

The essential oil of the genus Origanum is composed mainly of the phenols carvacrol (83\%) and lesser thymol (1.6-2.8\%), while the essential oils from Lippia origanoides contains high levels of thymol (67.2-78.7\%) and low levels of carvacrol $(0.9-1.2 \%)^{(2)}$. Essential oils derived from Origanum 
vulgare subsp. hirtum have been reported to possess: antioxidant ${ }^{(3)}$, antimicrobial ${ }^{(4)}$, insecticidal ${ }^{(5)}$, and antifungal ${ }^{(6)}$. In vitro studies have demonstrated activity against both gram-negative and grampositive bacteria $^{(4)}$. However, the OEO from Lippia origanoides Kuth, native from Central and South America, have not been studied as feed additives for broiler. Lippia oreganoides, commonly known in Spanish as Oregano de Monte, is mainly found in xerophytic scrub throughout semi-arid regions in Colombia. The main activity of the people inhabiting this landscape is subsistence agriculture and an economy of backwardness.

Stability is a very important attribute to raw poultry meat and its whole cuts prior to storage. In order to increase food storage stability, food industry uses synthetic antioxidants. However, the use of these synthetic antioxidants, such as butylated hydroxytoluene (BHT) and butylated hydroxyanisole (BHA), has come into concern due to their suspected carcinogenic potential(7). For these reasons, there is a research interest in the employment of natural additives as potential antioxidants.

Herb spices belongs to the family Lamiaceae, such as oregano and thyme, which have showed strong antioxidant activity comparable to synthetic antioxidants. In this context, our research group has been working for the past five years with Lippia origanoides Kuth thymol-rich OEO chemotype (>70\%) that has demonstrated antimicrobial and antioxidant properties in vitro and in vivo exploratory studies. Therefore, the thymol-rich OEO chemotype emerges as a natural niche alternative to be used as a functional promoter for poultry meat production. The aim of this study, thus, was to evaluate the effects of two OEO chemotypes on broiler growth performance, nutrient balance, and lipid peroxidation of breast meat during storage.

\section{Materials and Methods}

This study was carried out at CORPOICA Research Center, Bogota, Colombia. It was conducted within the guidelines approved by the Animal Care and Bioethics Committee of CORPOICA. The sources of OEO were the South American Lippia Origanoides (LO) and the oregano essential oil (Origanum vulgare subsp. hirtum) Synergy Essence, a commercially available product (SE; Ralco Nutrition, Inc. Marshall, MN USA).

Experiment 1: Two thousand one-day-old male broilers (Ross) were obtained a from commercial hatchery. Broilers were weighed individually and assigned randomly to 40 pens of 50 chicks each. Five pens were used for each dietary treatment. Eight treatments were used:

1. Basal diets without OEO or antibiotic (BD)

2. Basal diets plus bacitracin $50 \mathrm{~g} /$ ton of feed (AGP)

3. Basal diets plus Lippia origanoides $125 \mathrm{~g} /$ ton (LO125)

4. Basal diets plus Lippia origanoides $250 \mathrm{~g} / \mathrm{ton}$ (LO250)

5. Basal diets plus Lippia origanoides $500 \mathrm{~g} / \mathrm{ton}$ (LO500)

6. $\quad$ Basal diets plus SE (Origanum vulgare subsp. Hirtum) $125 \mathrm{~g} / \mathrm{ton}$ (SE125)

7. Basal diets plus SE (Origanum vulgare subsp. Hirtum) $250 \mathrm{~g} / \mathrm{ton}$ (SE250)

8. Basal diets plus SE (Origanum vulgare subsp. Hirtum) $500 \mathrm{~g} / \mathrm{ton}$ (SE500) 
The composition of the basal diets is shown in Table 1. It represents the feed specification of the two feeding phases: starter (1-21 days of age) and growth (21-42 days of age). The chickens had ad libitum access to feed and water.

Table 1. Composition of the basal diets used in the experiments

\begin{tabular}{|c|c|c|}
\hline Ingredient, \% & Starter (1-21 d) & Growth (21-42 d) \\
\hline Corn & 57.45 & 57.00 \\
\hline Soybean meal & 30.00 & 23.73 \\
\hline Extruded soybean & - & 6.27 \\
\hline Rice polishing & 8.00 & 8.00 \\
\hline Fish meal & 0.57 & - \\
\hline Soybean oil & 0.34 & 2.01 \\
\hline Tricalcium phosphate & 1.42 & 1.24 \\
\hline Calcium carbonate & 0.52 & 0.40 \\
\hline Salt & 0.35 & 0.35 \\
\hline Sodium bicarbonate & 0.30 & 0.30 \\
\hline DL-Methionine & 0.29 & 0.19 \\
\hline L-Lysine $\mathrm{HCl}$ & 0.28 & 0.12 \\
\hline L-Threonine & 0.11 & 0.02 \\
\hline Cl. Choline $60 \%$ & 0.07 & 0.07 \\
\hline $\begin{array}{l}\text { Vitamin-trace mineral } \\
\text { premix }^{1}\end{array}$ & 0.30 & 0.30 \\
\hline \multicolumn{3}{|c|}{ Calculated composition } \\
\hline $\mathrm{ME}(\mathrm{Mcal} / \mathrm{Kg})$ & 2950 & 3100 \\
\hline Crude Protein (\%) & 22 & 20 \\
\hline Lysine & 1.20 & 1.10 \\
\hline Calcium & 1.06 & 0.90 \\
\hline Available phosphorus & 0.53 & 0.50 \\
\hline
\end{tabular}

Body weights (BW) were recorded weekly by weighing the birds of each treatment and recording their total body weight. Average body weight was obtained by body weights took at the end of each week for each treatment and divided by the number of birds in each treatment. Feed was supplied continuously by topping up the empty feeder pan. The pans were filed to up to three quarter of its capacity to minimize feed waste. Feed intake was taken at the end of each feeding phase for each treatment by subtracting the amount of feed left from the amount of feed supplied daily and dividing it by the number of birds in each pen to obtain the average feed intake per bird per replicate. Feed consumed by the birds in each treatment was recorded per feeding phase on a per pen basis. Body weight gain (BWG), feed intake (FI), feed conversion (FC) and feed efficiency (FE) were determined for each feeding phase and for the total period (1-42 days of age). 
Carcass yield was evaluated at $42 \mathrm{~d}$ of age. One bird per replicate close to the average pen weight (5 birds per treatment) was selected and slaughtered. The birds were killed by cervical dislocation, bled, eviscerated and chilled, and then carcass was cut out for the measurement of its parts. Prior to chilling, the left portion of the breast was minced with a conventional meat grinder. From this sample, a fresh sample and three subsamples were wrapped in an oxygen-permeable polyethylene film and stored at $-4{ }^{\circ} \mathrm{C}$ for 3,6 , and 9 days. All samples were vacuum-packed and stored at $-20{ }^{\circ} \mathrm{C}$ until analysis of the thiobarbituric acid reactive substances (TBARS) by using the aqueous acid extraction method to determine lipid oxidation.

Experiment 2: Two hundred one-day-old male broilers (Ross) were obtained from a commercial hatchery. Metabolic batteries facilities were used in this experiment. Broilers were weighed individually and assigned randomly to 40 cages of five chicks each. Five cages were used for each dietary treatment. At 15 days of age, the effect of OEO on energy and nitrogen balance was evaluated. Chromium oxide $\left(\mathrm{Cr}_{2} \mathrm{O}_{3}\right)$ was added to the starter diet described in Experiment 1 as an indigestible marker $(0.5 \mathrm{~g} / \mathrm{kg}$ of diet $)$ and feed and water were provided ad libitum. Birds were individually weighed at the beginning (21-d) and at the end (24-d) of the collection period. Excreta samples were collected daily over a 3-day period and pooled by replicate. The formulas to calculate nutrient digestibility, apparent metabolizable energy (AME), and nitrogen-corrected apparent metabolizable energy (AMEn) were:

Indigestibility Factor $(\mathrm{IF})=\mathrm{Cr}$ Diet $(\mathrm{g} / \mathrm{g}) / \mathrm{Cr}$ Excreta $(\mathrm{g} / \mathrm{g})$

Nutrient Digestibility (Dx) $=(\%$ nutrient diet- $(\%$ nutrient excreta $) * I F)) / \%$ nutrient diet $\mathrm{AME}$ of a diet $=\mathrm{GE} \operatorname{diet}(\mathrm{kcal} / \mathrm{g})-[\mathrm{GE}$ excreta $(\mathrm{kcal} / \mathrm{g}) \times \mathrm{IF}]$

$\operatorname{AMEn}(\mathrm{Kcal} / \mathrm{Kg})=\mathrm{GE} \operatorname{diet}(\mathrm{kcal} / \mathrm{g})-[(\mathrm{GE}$ excreta $(\mathrm{kcal} / \mathrm{g}) * \mathrm{IF})+8.22 *(\mathrm{NB})]$

$\mathrm{NB}($ Nitrogen Balance $)=\mathrm{N}$ diet $-(\mathrm{N}$ excreta $* \mathrm{IF})$

Excreta samples for each replicate were dried at $50{ }^{\circ} \mathrm{C}$ for about $96 \mathrm{~h}$. The dried samples were ground through a $1-\mathrm{mm}$ sieve for chemical analysis. To determine dry matter, feed and excreta samples were dried at $105^{\circ} \mathrm{C}$. Gross energy (GE) was determined in an adiabatic bomb calorimeter. Nitrogen in feed and excreta samples were analyzed by the Kjeldahl method. Chromic oxide in feed and excreta samples were measured by the spectophotometric method.

Statistical Analyses: Data for body weight (BW), average daily gain (ADG), average daily feed intake (ADFI), gain/feed, average metabolize energy (AME), digestibility organic matter (OM), gross energy intake (GEI), nitrogen-corrected metabolizable energy (MEIn), metabolize energy/gross energy (ME/GE), nitrogen (N) digestibility, nitrogen intake $(\mathrm{NI})$, retain nitrogen $(\mathrm{RN})$, were analyzed using PROC GLIMMIX in the SAS Statistical Software 9.3, as a completely randomized design. Each pen or cage served as an experimental unit. MDA concentration in meat samples storage at 0 , 3, 6, 9 days was analyzed using PROC GLIMMIX as a completely randomized design with repeated measures. In both analyses, single degree-of-freedom orthogonal contrasts were used to compare means.

\section{Results and discussion}

The current study provides an evaluation of two chemotypes of oregano essential oils (OEO) as 
emerging feed additive to improve the performance and meat quality of broilers. The development and evaluation of OEOs chemotypes in broiler feeding systems have not been documented and these results constitute a comparative advantage to promote the biodiversity and total quality of broiler production.

\section{Experiment 1:}

Broiler performance: The results of the effect of two OEO chemotypes on broilers performance at 1 to 21 days, 21 to 42 days, and 42 days are shown in Tables 2, 3, and 4. In the starter phase (1-21 days, Table 2), BWG, FC, and FE were not affected by treatments $(\mathrm{P}>0.05)$. However, BWG was higher for LO vs SE $(+29 \mathrm{~g}$, SE 15.2, P $<0.06)$. Further analysis of the orthogonal contrast showed a significant effect between AGP and OEO $(-60 \mathrm{~g}$, SE 23.5, P<0.06) on FI, so that birds fed with OEO had a higher FI.

Table 2. Effect of two OEO chemotypes on broilers performance during starter phase (1-21

d) $($ mean \pm SE $)$

\begin{tabular}{lcccc}
\hline \multicolumn{1}{c}{ Treatment } & BWG (g) & FI (g) & FC (g/g) & FE (g/g) \\
\hline BD & $672 \pm 8.9$ & $913 \pm 19.7$ & $1.36 \pm 0.03$ & $0.74 \pm 0.02$ \\
AGP & $626 \pm 13.4$ & $829 \pm 25.0$ & $1.33 \pm 0.05$ & $0.76 \pm 0.03$ \\
LO125 & $681 \pm 30.7$ & $923 \pm 21.7$ & $1.36 \pm 0.04$ & $0.74 \pm 0.02$ \\
LO250 & $655 \pm 10.0$ & $874 \pm 12.8$ & $1.33 \pm 0.02$ & $0.75 \pm 0.01$ \\
LO500 & $678 \pm 17.1$ & $902 \pm 13.4$ & $1.33 \pm 0.04$ & $0.75 \pm 0.02$ \\
SE125 & $670 \pm 32.0$ & $898 \pm 16.0$ & $1.35 \pm 0.05$ & $0.75 \pm 0.03$ \\
SE250 & $630 \pm 2.5$ & $862 \pm 23.5$ & $1.37 \pm 0.03$ & $0.73 \pm 0.02$ \\
SE500 & $628 \pm 11.2$ & $878 \pm 25.09$ & $1.40 \pm 0.02$ & $0.72 \pm 0.01$ \\
P-value & 0.1795 & 0.0644 & 0.9171 & 0.9062 \\
\hline & & Contrasts P-value & & \\
BD vs Additives & 0.3234 & 0.1349 & 0.8856 & 0.8608 \\
AGP vs OEO & 0.1670 & 0.0149 & 0.4911 & 0.4785 \\
LO vs SE & 0.0650 & 0.2143 & 0.3590 & 0.3812 \\
LO Linear & 0.9045 & 0.4605 & 0.6199 & 0.6010 \\
LO Quadratic & 0.2845 & 0.1182 & 0.7834 & 0.8421 \\
SE Linear & 0.1192 & 0.4768 & 0.3723 & 0.3223 \\
SE Quadratic & 0.4187 & 0.2856 & 0.8892 & 0.9227 \\
\hline
\end{tabular}

Means with different superscripts in the same row differ significantly $(\mathrm{P}<0.05)$.

$\mathrm{LO}=$ Oregano Essential Oil Lippia origanoides; $\mathrm{SE}=$ oregano essential oil (Origamm vulgare subsp. hirtum) product Synergy Essence.

Results of feed intake during the starter phase in this experiment are in agreement with Roofchaee et al. ${ }^{(8)}$, as feed intake was not affected by OEO supplementation. Cross et al. ${ }^{(9)}$ also reported that feed intake of broilers fed $1000 \mathrm{ppm}$ of OEO/kg of diet was not affected between 7-28 days of age. Thymol is the major component of Lippia origanoides essential oils, while carvacrol, an isomer of thymol, is the major component in Origanum vulgare subsp. Hirtum essential oils. Therefore, during this phase, the thymol-rich essential oil chemotype (LO) resulted in a higher body weight compared to the carvacrol-rich essential oil chemotype (SE). 
Table 3. Effect of two OEO chemotypes on broilers performance during growth phase (21$42 \mathrm{~d})($ mean $\pm \mathrm{SE})$

\begin{tabular}{lcccc}
\hline \multicolumn{1}{c}{ Treatment } & BWG (g) & FI (g) & FC $(\mathbf{g} / \mathbf{g})$ & FE $(\mathbf{g} / \mathbf{g})$ \\
\hline BD & $1280 \pm 43.6$ & $2470 \pm 105.8$ & $1.95 \pm 0.13$ & $0.52 \pm 0.04$ \\
AGP & $1450 \pm 37.2$ & $2122 \pm 158.9$ & $1.47 \pm 0.14$ & $0.70 \pm 0.06$ \\
LO125 & $1505 \pm 71.2$ & $2426 \pm 33.4$ & $1.63 \pm 0.08$ & $0.62 \pm 0.03$ \\
LO250 & $1512 \pm 25.0$ & $2609 \pm 77.8$ & $1.73 \pm 0.05$ & $0.58 \pm 0.02$ \\
LO500 & $1426 \pm 70.3$ & $2494 \pm 127.4$ & $1.77 \pm 0.12$ & $0.58 \pm 0.04$ \\
SE125 & $1439 \pm 52.1$ & $2427 \pm 92.8$ & $1.69 \pm 0.09$ & $0.60 \pm 0.03$ \\
SE250 & $1632 \pm 58.0$ & $2486 \pm 120.5$ & $1.54 \pm 0.12$ & $0.67 \pm 0.06$ \\
SE500 & $1509 \pm 41.2$ & $2472 \pm 68.0$ & $1.64 \pm 0.03$ & $0.61 \pm 0.01$ \\
P-value & 0.0053 & 0.1541 & 0.0767 & 0.1171 \\
\hline & & Contrasts P-value & & \\
\hline BD vs Additives & 0.0005 & 0.7371 & 0.0061 & 0.0237 \\
AGP vs OEO & 0.3919 & 0.0046 & 0.1074 & 0.0629 \\
LO vs SE & 0.2959 & 0.5618 & 0.3196 & 0.3302 \\
LO Linear & 0.2957 & 0.6320 & 0.3251 & 0.4315 \\
LO Quadratic & 0.4660 & 0.2338 & 0.8096 & 0.7008 \\
SE Linear & 0.3540 & 0.7492 & 0.6931 & 0.7950 \\
SE Quadratic & 0.0193 & 0.7644 & 0.2956 & 0.1856 \\
\hline
\end{tabular}

Means with different superscripts in the same row differ significantly $(\mathrm{P}<0.05)$.

$\mathrm{LO}=$ Oregano Essential Oil Lippia origanoides; $\mathrm{SE}=$ oregano essential oil (Origamum vulgare subsp. hirtum) product Synergy Essence.

Poultry's sensitivity to taste and smell is lower compared to other animals; however, the flavor of poultry diet can stimulate or depress feed intake ${ }^{(10)}$. Phenolic terpenes, such as thyme oil, may give an unpleasant taste to diets offered to growing chickens as it was reported by Cross et al. ${ }^{(11)}$. In the present study, AGP resulted in a lower feed intake compared with OEO at the higher level of inclusion, regardless of chemotypes. In this sense, the stimulating effect of OEO on appetite depends on the level of essential oil inclusion to the diet and the age of the bird ${ }^{(12)}$.

During the growth phase (21 to 42 days, Table 3$)$, a significant effect was seen for BWG $(\mathrm{P}<0.01)$ and tendencies were observed for FI $(\mathrm{P}<0.16), \mathrm{FC}(\mathrm{P}<0.08)$, and FE $(\mathrm{P}<0.12)$. Analysis of contrasts showed that BWG was higher for feed additives vs BD (+217 g, SE 55.9, P $<0.01)$, and SE showed a quadratic response associated with SE500 treatment $(\mathrm{P}<0.05)$. FI was higher for AEO vs AGP $(+364 \mathrm{~g}, \mathrm{SE} 119.0, \mathrm{P}<0.01)$, while FC was higher for BD vs feed additives $(+0.3, \mathrm{SE} 0.11, \mathrm{P}<0.05)$. FE was lower for BD vs feed additives $(-0.1$, SE 0.041, $\mathrm{P}<0.05)$, but it was higher for AGP vs OEO $(+0.09$, SE 0.046, $\mathrm{P}<0.06)$.

During the total period ( 1 to 42 days, Table 4), significant effects were observed for BWG and FI $(\mathrm{P}<0.05)$, but FC and FE presented tendencies $(\mathrm{P}<0.10$ and $\mathrm{P}<0.14$, respectively). A further analysis of orthogonal contrasts showed a similar response observed during growth phase for BWG, i.e., it was lower for BD vs feed additives (-196 g, SE 61.2, P $<0.01)$, and SE showed a quadratic response associated with SE500 treatment $(\mathrm{P}<0.06)$. FI was higher for OEO vs AGP $(+424 \mathrm{~g}$, SE 114.3, P $<0.01)$, so that FC was lower for AGP vs OEO (-0.14, SE 0.07, P < 0.08). The contrast BD 
vs feed additives affected FC $(+0.19$, SE $0.069, \mathrm{P}<0.01)$ and $\mathrm{FE}(-0.07, \mathrm{SE} 0.030, \mathrm{P}<0.05)$. FE was higher for AGP vs OEO $(+0.07$, SE 0.033, P $<0.06)$.

Table 4. Effect of two OEO chemotypes on broilers performance during the total period of 42 -d (mean $\pm \mathrm{SE})$

\begin{tabular}{lcccc}
\hline Treatment & BWG 42-d (g) & FI 42-d (g) & FC42-d (g/g) & FE 42-d (g/g) \\
\hline BD & $1952 \pm 50.9^{\mathrm{b}}$ & $3383 \pm 119.9$ & $1.74 \pm 0.09$ & $0.58 \pm 0.03$ \\
AGP & $2076 \pm 44.4^{\mathrm{ab}}$ & $2951 \pm 137.5$ & $1.43 \pm 0.08$ & $0.71 \pm 0.04$ \\
LO125 & $2186 \pm 91.0^{\mathrm{ab}}$ & $3349 \pm 20.4$ & $1.54 \pm 0.06$ & $0.65 \pm 0.03$ \\
LO250 & $2168 \pm 22.2^{\mathrm{ab}}$ & $3482 \pm 66.1$ & $1.61 \pm 0.03$ & $0.62 \pm 0.01$ \\
LO500 & $2104 \pm 80.7^{\mathrm{ab}}$ & $3396 \pm 128.6$ & $1.62 \pm 0.08$ & $0.62 \pm 0.04$ \\
SE125 & $2109 \pm 37.1^{\mathrm{ab}}$ & $3325 \pm 96.7$ & $1.58 \pm 0.04$ & $0.64 \pm 0.02$ \\
SE250 & $2262 \pm 58.0^{\mathrm{a}}$ & $3348 \pm 107.2$ & $1.49 \pm 0.08$ & $0.68 \pm 0.04$ \\
SE500 & $2136 \pm 38.1^{\mathrm{ab}}$ & $3350 \pm 59.6$ & $1.57 \pm 0.02$ & $0.64 \pm 0.01$ \\
P-value & 0.0372 & 0.0543 & 0.0920 & 0.1332 \\
\hline & & Contrasts P-value & & \\
\hline BD vs Additives & 0.0030 & 0.5089 & 0.0087 & 0.0249 \\
AGP vs OEO & 0.2189 & 0.0008 & 0.0736 & 0.0553 \\
LO vs SE & 0.7287 & 0.3903 & 0.3927 & 0.4300 \\
LO Linear & 0.3191 & 0.7285 & 0.3777 & 0.4643 \\
LO Quadratic & 0.7505 & 0.3571 & 0.7610 & 0.6641 \\
SE Linear & 0.7367 & 0.8520 & 0.9264 & 0.9640 \\
SE Quadratic & 0.0553 & 0.9274 & 0.2941 & 0.2128 \\
\hline
\end{tabular}

Means with different superscripts in the same row differ significantly $(\mathrm{P}<0.05)$.

$\mathrm{LO}=$ Oregano Essential Oil Lippia origamoides; $\mathrm{SE}=$ oregano essential oil (Origamum vulgare subsp. hirtum) product Synergy Essence.

Many studies with OEO have not shown consistent results in broilers. The effectiveness of the use of OEO in broilers is affected by dose, concentration of active components, infection, diet composition, and environment ${ }^{(13)}$. Different studies have not shown a beneficial effect of OEO supplementation on broilers growth ${ }^{(9,14)}$. However, OEO supplementation in drinking water at doses of 150 or $400 \mathrm{~mL}$ per ton improved broilers performance ${ }^{(15)}$. These responses are more effective in the early growth period of chickens, where environmental factors and nutritional stress may depress broilers growth ${ }^{(16)}$. In general, growth promoting supplements have not showed a positive response when used in clean environments and with a moderate density birds, similar to the experimental condition of this study ${ }^{(17)}$.

In this study, the experimental results indicate the dietary treatments did not affect body weight at slaughter, carcass yield, breast yield, and abdominal fat deposition in broilers at 42 days of age (Table 5). The average body weight at slaughter was $2168 \mathrm{~g}$, while the averages for carcass yield, breast yield, and abdominal fat deposition were $66.7 \%, 38.9 \%, 1.21 \%$, respectively. Similar results were obtained for early maturing female turkeys supplemented with oregano leaves from the carvacrol-rich SE chemotype ${ }^{(18)}$. 
Table 5. Effect of two OEO chemotypes on carcass characteristics (mean $\pm \mathrm{SE}$ )

\begin{tabular}{lcccc}
\hline Treatment & $\begin{array}{c}\text { BW slaughter } \\
(\mathbf{g})\end{array}$ & $\begin{array}{c}\text { Carcass yield } \\
(\%)\end{array}$ & Breast yield (\%) & $\begin{array}{c}\text { Abdominal fat } \\
\text { deposition (\%) }\end{array}$ \\
\hline BD & $2064 \pm 29.9$ & $67.0 \pm 0.47$ & $38.1 \pm 1.34$ & $1.22 \pm 0.18$ \\
AGP & $2120 \pm 40.0$ & $67.1 \pm 0.68$ & $38.1 \pm 0.47$ & $1.49 \pm 0.09$ \\
LO125 & $2220 \pm 95.5$ & $67.8 \pm 0.91$ & $39.2 \pm 1.65$ & $0.94 \pm 0.10$ \\
LO250 & $2168 \pm 47.6$ & $63.1 \pm 4.88$ & $40.5 \pm 0.99$ & $1.28 \pm 0.17$ \\
LO500 & $2120 \pm 79.3$ & $66.9 \pm 0.88$ & $37.6 \pm 1.05$ & $0.98 \pm 0.14$ \\
SE125 & $2188 \pm 16.3$ & $67.0 \pm 0.27$ & $39.0 \pm 0.91$ & $1.31 \pm 0.19$ \\
SE250 & $2272 \pm 57.8$ & $67.2 \pm 1.00$ & $39.8 \pm 0.88$ & $1.51 \pm 0.23$ \\
SE500 & $2184 \pm 47.9$ & $67.0 \pm 1.53$ & $39.0 \pm 0.86$ & $0.96 \pm 0.19$ \\
P-value & 0.5605 & 0.7707 & 0.5999 & 0.1226 \\
\hline & & Contrasts P-value & & \\
\hline BD vs Additives & 0.0643 & 0.8644 & 0.4243 & 0.9748 \\
AGP vs OEO & 0.2991 & 0.8016 & 0.3961 & 0.1111 \\
LO vs SE & 0.3399 & 0.5035 & 0.8603 & 0.1676 \\
LO Linear & 0.2263 & 0.6951 & 0.2856 & 0.8565 \\
LO Quadratic & 0.9774 & 0.0787 & 0.1193 & 0.1318 \\
SE Linear & 0.9609 & 0.9989 & 0.9871 & 0.1583 \\
SE Quadratic & 0.2294 & 0.9292 & 0.5722 & 0.0751 \\
\hline
\end{tabular}

Means with different superscripts in the same row differ significantly $(\mathrm{P}<0.05)$

$\mathrm{LO}=$ Oregano Essential Oil Lippia origanoides; $\mathrm{SE}=$ oregano essential oil (Origamum vulgare subsp. hirtum) product Synergy Essence.

Lipid oxidation: Oregano has been studied for their antioxidant activity ${ }^{(19)}$. The potential of dietary essential oils and aromatic plants to improve the oxidative stability of meat obtained from broilers has already been demonstrated ${ }^{(17,20-23)}$. The effects of two OEO chemotypes and storage time at $4{ }^{\circ} \mathrm{C}$ on lipid oxidation of breast meat are shown in Table 6 . The extent of lipid oxidation, measured by malondialdehyde (MDA) concentration, showed significant differences between the experimental treatments and storage time. The MDA values increased $(+135 \%)$ during the nine days of storage $(\mathrm{P}<0.001)$. Breast meat of broilers from control and AGP groups showed higher concentration of MDA compared to the birds fed a diet with OEO $(\mathrm{P}<0.05)$. The lowest MDA concentration was observed in the group supplemented with SE500 and no differences were observed among groups supplemented with the two OEO chemotypes $(\mathrm{P}>0.05)$. The birds fed AGP showed the greatest lipid peroxidation when the breast meat was storage during 9 days at $-4{ }^{\circ} \mathrm{C}(147 \mathrm{ng} / \mathrm{g})$.

Poultry meat contains a low lipid content, but a high concentration of polyunsaturated fatty acids ${ }^{(23)}$. Thus, poultry meat is particularly susceptible to oxidative deterioration, which might contribute to its significant response regarding lipid oxidation generated by dietary OEO supplementation, as it was observed in this study. Similar findings were reported by Botsoglou et al., (24) showing that OEO addition significantly reduced lipid oxidation in raw meat, cooked turkey during storage and recooling - A lower oxidation in breast meat was found, probably due to the presence of the antioxidant constituents of the OEO. These antioxidants enter the circulatory system and are distributed and retained in muscle and other tissues. In this sense, Farag et al. ${ }^{(25)}$ suggested thymol has the highest antioxidant activity due to the presence of phenolic $\mathrm{OH}$ groups, which act as hydrogen donors to the 
peroxy radicals produced during the first step in lipid oxidation, thus, retarding the hydroxy peroxide formation. This antioxidant effect is dose dependent ${ }^{(13)}$.

Table 6. Effect of two OEO chemotypes and storage time at $-4{ }^{\circ} \mathrm{C}$ on malondialdehyde content on breast meat (mean $\pm \mathrm{SE}$ )

\begin{tabular}{lc}
\hline Treatment & MDA (ng/g) \\
\hline BD & $88.5 \pm 4.38^{\mathrm{a}}$ \\
AGP & $89.3 \pm 5.56^{\mathrm{a}}$ \\
LO125 & $79.0 \pm 4.62^{\mathrm{ab}}$ \\
LO250 & $72.8 \pm 4.70^{\mathrm{b}}$ \\
LO500 & $77.3 \pm 4.72^{\mathrm{ab}}$ \\
SE125 & $72.7 \pm 4.85^{\mathrm{b}}$ \\
SE250 & $74.1 \pm 4.70^{\mathrm{b}}$ \\
SE500 & $67.9 \pm 4.72^{\mathrm{b}}$ \\
P-value & 0.0370 \\
\hline
\end{tabular}

\begin{tabular}{lc}
\hline \multicolumn{2}{c}{ Storage time, days } \\
\hline 0 & $49.5 \pm 2.81^{\mathrm{a}}$ \\
3 & $59.8 \pm 2.80^{\mathrm{b}}$ \\
6 & $85.8 \pm 2.79^{\mathrm{c}}$ \\
9 & $115.9 \pm 2.84^{\mathrm{d}}$ \\
P-value & $<0.0001^{\mathrm{P}}$ \\
\hline
\end{tabular}

\begin{tabular}{ll}
\hline \multicolumn{2}{c}{ Contrasts P-Value } \\
\hline BD vs Additives & 0.0143 \\
AGP vs OEO & 0.0142 \\
LO vs BD+SE & 0.2213 \\
LO Linear & 0.8016 \\
LO Quadratic & 0.3545 \\
SE Linear & 0.4855 \\
SE Quadratic & 0.5256 \\
\hline
\end{tabular}

Means with different superscripts in the same row differ significantly $(\mathrm{P}<0.05)$.

$\mathrm{MDA}=$ Malondialdehyde; $\mathrm{LO}=$ Oregano Essential Oil Lippia origamoides $; \mathrm{SE}=$ oregano essential oil

(Origamum vulgare subsp. hirtum) product Synergy Essence.

According to Pereira and Maia ${ }^{(26)}$, the phenolic compounds present in many essential oils have an antioxidant function; therefore, they act as hydrogen donors, decreasing hydrogen peroxide production. The antioxidant activity of various herbs showed that Origanum vulgare presents a high antioxidant activity and has the greatest ability to eliminate reactive oxygen species (free radicals) ${ }^{(27)}$. This can be explained by the high content of phenolic compounds found in Origanum vulgare. Therefore, the extract and oregano oil are considered a source of natural antioxidants and may be used as food preserver.

Experiment 2: The effects of two OEO chemotypes on nutrient balance are shown in Tables 7 and 8. The apparent digestibility coefficients of OM, GE intake, AMEn and metabolizability of the dietary energy (AME:GE) were determined. $\mathrm{N}$ digestibility, $\mathrm{N}$ intake and nitrogen retention (NR) were also 
determined. Broilers fed LO500 had greater $(\mathrm{P}<0.05)$ OM digestibility than broilers in control group. There were no differences in OM digestibility, energy, or nitrogen metabolism among AGP, LO, or SE fed birds. Control birds had lower OM digestibility (-4.6\%) and AME/GE (-0.036) compared to birds fed the AGP or OEO diets $(\mathrm{P}<0.05)$. Birds in LO groups showed tendency $(\mathrm{P}<0.10)$ to increase $\mathrm{OM}$ digestibility and $\mathrm{AME} / \mathrm{GE}$ as the inclusion level of LO increased, while within the SE group, the inclusion level showed a quadratic effect showing the highest value of OM digestibility and AME/GE ratio in the SE250 fed birds. The value for OM digestibility was in accordance with the value for AME:GE. There were no differences in nitrogen metabolism among AGP, LO, or SE fed birds. However, data showed a numerical increase of NR $\left(+1.22 \mathrm{mg} /\right.$ day $\left./\left(\mathrm{kg} \mathrm{wt}^{0.75}\right)^{-1} \mathrm{~d}-1\right)$ in birds fed AGP, LO, or SE compared to control. Birds fed OEO also showed a numerical increase of NR $\left(+0.72 \mathrm{mg} / \mathrm{day} /\left(\mathrm{kg} \mathrm{wt}^{0.75}\right)^{-1 \mathrm{~d}-1}\right)$ compared to birds fed AGP diet.

Table 7. Effect of two OEO chemotypes on energy metabolism of broilers from 21 to 24 days of age (mean $\pm \mathrm{SE})$

\begin{tabular}{|c|c|c|c|c|}
\hline Treatment & $\begin{array}{c}\text { OM } \\
\text { digestibility } \\
(\%)\end{array}$ & $\begin{array}{c}\text { GE Intake } \\
\text { (kg wt 0.75)-1 d- } \\
1\end{array}$ & $\begin{array}{c}\text { AMEn Intake } \\
\text { (kg wt 0.75)-1 } \\
\text { d-1 } \\
\end{array}$ & AME/GE \\
\hline $\mathrm{BD}$ & $62.2 \pm 1.73^{b}$ & $2013 \pm 116.89$ & $1385 \pm 100.65$ & $0.68 \pm 0.02$ \\
\hline AGP & $67.7 \pm 2.96^{\mathrm{ab}}$ & $2052 \pm 209.91$ & $1510 \pm 203.96$ & $0.72 \pm 0.03$ \\
\hline LO125 & $65.3 \pm 1.07^{\mathrm{ab}}$ & $2002 \pm 87.94$ & $1423 \pm 70.21$ & $0.71 \pm 0.01$ \\
\hline LO250 & $64.9 \pm 1.25^{\mathrm{ab}}$ & $2260 \pm 332.87$ & $1606 \pm 245.86$ & $0.70 \pm 0.01$ \\
\hline LO500 & $69.8 \pm 0.79^{a}$ & $2264 \pm 67.59$ & $1695 \pm 58.92$ & $0.74 \pm 0.01$ \\
\hline SE125 & $67.0 \pm 0.61^{a b}$ & $2142 \pm 78.21$ & $1551 \pm 67.15$ & $0.72 \pm 0.01$ \\
\hline SE250 & $69.1 \pm 1.59 \mathrm{ab}$ & $2226 \pm 58.78$ & $1653 \pm 62.44$ & $0.74 \pm 0.02$ \\
\hline SE500 & $63.5 \pm 2.89^{a b}$ & $2176 \pm 59.05$ & $1509 \pm 49.93$ & $0.69 \pm 0.02$ \\
\hline P-value & 0.0410 & 0.8271 & 0.6123 & 0.0660 \\
\hline \multicolumn{5}{|c|}{ Contrasts P-value } \\
\hline BD vs Additives & 0.0177 & 0.3674 & 0.1806 & 0.0298 \\
\hline AGP vs OEO & 0.5969 & 0.4873 & 0.6652 & 0.6855 \\
\hline LO vs SE & 0.9100 & 0.9621 & 0.9691 & 0.8693 \\
\hline LO Linear & 0.0709 & 0.2293 & 0.1252 & 0.0836 \\
\hline LO Quadratic & 0.2113 & 0.4974 & 0.7522 & 0.2413 \\
\hline SE Linear & 0.1624 & 0.8735 & 0.8095 & 0.1789 \\
\hline SE Quadratic & 0.0750 & 0.7219 & 0.4159 & 0.0797 \\
\hline
\end{tabular}

Means with different superscripts in the same row differ significantly $(\mathrm{P}<0.05)$.

$\mathrm{LO}=$ Oregano Essential Oil Lippia origanoides; $\mathrm{SE}=$ oregano essential oil (Origamum vulgare subsp. hirtum) product Synergy Essence.

An important effect of additive natural substances is their benefits to gastrointestinal enzymatic activity related with the better nutrients digestibility ${ }^{(28)}$. Moreover, the availability of nutrients can be increased by altering the intestinal microbial population, which favors nutrients absorption. Therefore, some plant extracts stimulate digestion process and produce changes on the gut microbiota mainly by regulating the $\mathrm{pH}$ of the gut, thereby increasing the digestibility of the nutrients and reducing the pathogenic bacterial growth ${ }^{(29)}$. In this sense, OEO increases the digestibility of nutrients and favors the balance of the microbiota, decreasing the potential for adhesion of pathogens in the 
intestinal epithelium ${ }^{(30)}$.

Table 8. Effect of two OEO chemotypes on nitrogen metabolism of broilers from 21 to 24 days of age (mean $\pm \mathrm{SE})$

\begin{tabular}{lccc}
\hline Treatment & $\begin{array}{c}\text { N digestibility } \\
(\%)\end{array}$ & $\begin{array}{c}\text { N Intake } \\
\text { g/d/(kg wt 0.75)-1 d-1 }\end{array}$ & $\begin{array}{c}\text { RN } \\
\text { mg/d/(kg wt 0.75)-1 d-1 }\end{array}$ \\
\hline BD & $45.4 \pm 5.10$ & $1.60 \pm 0.09$ & $7.43 \pm 1.10$ \\
AGP & $48.1 \pm 4.36$ & $1.63 \pm 0.17$ & $8.03 \pm 1.49$ \\
LO125 & $48.4 \pm 2.33$ & $1.59 \pm 0.07$ & $7.69 \pm 0.48$ \\
LO250 & $49.5 \pm 2.06$ & $1.80 \pm 0.26$ & $8.93 \pm 1.37$ \\
LO500 & $54.8 \pm 2.38$ & $1.80 \pm 0.05$ & $9.88 \pm 0.50$ \\
SE125 & $48.7 \pm 2.28$ & $1.70 \pm 0.06$ & $8.30 \pm 0.54$ \\
SE250 & $55.3 \pm 4.25$ & $1.77 \pm 0.05$ & $9.78 \pm 0.76$ \\
SE500 & $46.0 \pm 6.42$ & $1.73 \pm 0.05$ & $7.92 \pm 1.06$ \\
P-value & 0.5157 & 0.8271 & 0.4642 \\
\hline & & Contrasts P-value & 0.2372 \\
\hline BD vs Additives & 0.2630 & 0.3674 & 0.5244 \\
AGP vs OEO & 0.6140 & 0.4873 & 0.8282 \\
LO vs SE & 0.7728 & 0.9621 & 0.1112 \\
LO Linear & 0.2464 & 0.2293 & 0.8976 \\
LO Quadratic & 0.6617 & 0.4974 & 0.7776 \\
SE Linear & 0.6285 & 0.8735 & 0.1571 \\
\hline SE Quadratic & 0.1030 & 0.7219 & \\
\hline
\end{tabular}

Means with different superscripts in the same row differ significantly $(\mathrm{P}<0.05)$.

$\mathrm{LO}=$ Oregano Essential Oil Lippia origamoides; $\mathrm{SE}=$ oregano essential oil (Origamm vulgare subsp. hirtum) product Synergy Essence.

A large volume of studies with OEO indicate that feed intake is reduced without altering the body weight gain and cumulative body weight, leading to an improvement in feed conversion during commercial broiler market cycle. Different experimental approaches - related to the active components and effective dose supplied - have been implemented to use OEO in broiler diets; however, such approaches affect the results. Furthermore, the assessment of systemic potential effects is influenced by the botanical origin of oregano and its active components, which are more complex considering the availability of commercial products containing different mixtures of spices.

Specimens of oregano have been studied as natural additives around the world in terms of two chemotypes, depending on whether the dominant component of the essential oil is carvacrol or thymol. In the present study, the beneficial effects of OEO on broiler performance were evident and not dependent on chemotypes. The results indicate that broilers fed diets containing OEO grow faster than those fed a control diet and present a similar growth to broilers fed AGP. Some of these responses was explained by increased OM digestibility and energy use.

Lipid oxidation was prevented by OEO supplementation to broiler's diets. OEO had a greater effect than AGP and control diets in preventing lipid peroxidation of breast meat. There were no differences between OEO chemotypes; however, OEO proved its effectiveness in retaining quality of breast meat 
after 9 days of storage and they were more effective when provided at least at the dose of $125 \mathrm{mg} / \mathrm{kg}$. The expectation for this study was for OEO-supplemented broilers to perform at least equal to AGPsupplemented broilers if not better. As broilers fed the basal diet had different performance than broilers fed OEO and AGP, one might conclude that OEO, regardless of the chemotype, can replace AGP as an alternative additive in broiler feeding regimes.

As a replacement for AGP, OEO shows promising results in broiler production. The performance parameters were maintained as those from AGP-supplemented broilers. Besides, breast meat quality was improved compared to AGP-supplemented broilers. An improved breast meat quality preventing lipid peroxidation, as well as a residue free product, due to no AGP supplementation, meet the requirements of a healthy product and the current consumer's expectations.

\section{Conclusions}

It can be concluded that birds fed OEO grow faster than those fed a BD and present a similar growth to birds fed AGP with some of this response being possibly explained by increased digestibility and energy utilization. In addition, providing OEO from $\mathrm{SE}$ at $500 \mathrm{~g} / \mathrm{ton}$ in the diet of broilers resulted in lower lipid peroxidation in ground breast meat throughout the storage time tested.

\section{Acknowledgments}

The authors gratefully acknowledge the financial support by Ralco-Mix Inc. (Marshall, MN).

\section{References}

1. Jones FT, Ricke SC. Observations on the history of the development of antimicrobials and their use in poultry feeds. Poult. Sci. 2003; 82(4): 613-617. https://doi.org/10.1093/ps/82.4.613.

2. Ortiz RE, Afanador G, Vásquez DR, Ariza-Nieto C. Efecto del aceite esencial de orégano sobre el desempeño productivo de ponedoras y la estabilidad oxidativa de huevos enriquecidos con ácidos grasos poliinsaturados. Rev Med Vet Zoot. 2017; 64(1): 61-70. https://doi.org/10.15446/rfmvZ.v64n1.65829.

3. Economou KD, Oreopoulou V, Thomopoulos CD. Antioxidant activity of some plant extracts of the family Labiatae. J. Am. Oil Chem. Soc. 1991; 68(2): 109-113. https://doiorg.ezproxy.unal.edu.co/10.1007/BF02662329.

4. Janssen AM, Scheffer JJC, Baerheim Svendsen A. Antimicrobial activity of essential oils: a 1976-86 literature review. Aspects of the test methods. Planta Medica. 1987; 53: 395 398. DOI: 10.1055/s-2006962755.

5. Konstantopoulou L, Vassilopoulou L, Mauragani-Tsipidov P, Scouras ZG. Insecticidal effects of essential oils. A study of the effects of essential oils extracted from eleven Greek aromatic plants on D. auraria. 
Experientia. 1992; 48(6): 616-619. https://doi.org/10.1007/BF01920251.

6. Thompson DP. Fungitoxic activity of essential oil components on food storage fungi. Mycologia. 1989; 81:151-153. http://www.jstor.org/stable/3759462.

7. Shahidi F. Antioxidants in food and food antioxidants. Molecular Nutrir. 2000(3); 44: 158-163. doi:10.1002/1521-3803(20000501)44:3<158::AID-FOOD158>3.0.CO;2-L.

8. Roofchaee A, Mehrdad I, Ebrahimzadeh MA, Akbari MR. Effect of Dietary Oregano (Origanum vulgare L.) Essential Oil on Growth Performance, Cecal Microflora and Serum Antioxidant Activity of Broiler Chickens. Afr. J. Biotech. 2011; 10: 6177-6183. https://doi.org/10.5897/AJB10.2596

9. Cross DE, McDevitt RM, Hillman K, Acamovic T. The effects of herbs and their associated essential oils on performance, dietary digestibility and gut microflora in chickens from 7 to 28 days of age. Brit. Poult. Sci. 2007; 48: 496-506. https://doi.org/10.1080/00071660701463221.

10. Deyoe CW, Davies RE, Krishnan R, Khaund R Couch JR. Studies on the taste preference of the chick. Poult. Sci. 1962; 41(3): 781-784. https://doi.org/10.3382/ps.0410781

11. Cross DE, Svoboda K, McDevitt RM, Acamovic T. The performance of chickens fed diets with or without thyme oil and enzymes. Brit. Poult. Sci. 2003; 44: 18-19. https://doi.org/10.1080/713655293

12. Basmacioglu H, Baysal S, Misirlioglu Z, Polat M, Yilmaz H, Turan N. Effects of oregano essential oil with or without feed enzymeson growth performance, digestive enzyme, nutrient digestibility, lipid metabolism, and immune response of broilers fed on wheat-soybean meal diets. Br. Poult. Sci. 2010; 51:67-80. https://doi.org/10.1080/00071660903573702

13. Botsoglou NA, Florou-Paneri P, Christaki E, Fletouris DJ, Spais AB, Effect of dietary oregano essential oil on performance of chickens and on iron-induced lipid oxidation of breast, thigh and abdominal fat tissues. Br. Poult. Sci. 2002; 43: 223-230. https://doi.org/10.1080/00071660120121436

14. Basmacioglu HTokusogluo O, Ergul M. The effects of oregano and rosemary essential oils or alphatocopheryl acetate on performance and lipid oxidation of meat enriched with n-3 PUFAs in broilers. S Afr J Anim Sci. 2004; 34:197-210. http://www.sasas.co.za/sites/sasas.co.za/files/basmaciogluvol343 0.pdf

15. Hertrampf JW. Alternative antibacterial performance promoters. Poult. Int. 2001; 40: 50-52.

16. Surai PF. Effect of selenium and vitamin E content of the maternal diet on the antioxidant system of the yolk and the developing chick. Br Poult Sci. 2000(2); 41: 235-43. https://doi.org/10.1080/713654909

17. Botsoglou NA, Christaki E, Florou-Paneri P, Giannenas I, Papageorgiou G, Spais AB. The effect of a mixture of herbal essential oils or á-tocopheryl acetate on performance parameters and oxidation of body lipid in broilers. S. Afr. J. Anim. Sci. 2004; 34(1): 143-151. http://www.sasas.co.za/sites/sasas.co.za/files/botsoglouvol34no1 $0 . p d f$

18. Bampidis VA, Christodolou V, Florou-Paneri P, Christaki E, Spais AB, Chatzopolou PS. Effect of dietary dried oregano leaves supplementation on performance and carcass characteristics of growing lambs. Anim. Feed Sci. Technol. 2005; 121: 285-295. https://doi.org/10.1016/j.anifeedsci.2005.02.002

19. Brenes A, Roura E. Essential oils in poultry nutrition: main effects and modes of action. Anim. Feed Sci. Technol. 2010; 158: 1-14. https://doi.org/10.1016/j.anifeedsci.2010.03.007

20. Marcincak S, Cabadaj R, Popelka P, Soltysova L. Antioxidative effect of oregano supplemented to broilers on oxidative stability of poultry meat. Slov Vet Res. 2008(2); 45:61-66. https://www.slovetres.si/index.php/SVR/issue/viewIssue/31/34

21. Florou-Paneri P, Giannenas L, Christaki E, Govaris A, Botsoglou NA. Performance of chickens and oxidative stability of the produced meat as affected by feed supplementation with oregano, vitamin $\mathrm{C}$, vitamin 
E and their combinations. Arch. Geflugelk. 2006; 70(5), 232-240. https://www.european-poultryscience.com/artikel.dll/m0503mk NDIxNzE2NA.PDF?UID=F0935F9667087AE5401D59A341F439AF66753EC45671F2

22. Giannenas IA, Florou-Paneri P, Botsoglou NA, Christaki E, Spais A B. Effect of supplementing feed with oregano and/or $\alpha$-tocopheryl acetate on growth of broiler chickens and oxidative stability of meat. J. Anim. Feed Sci. 2005; 14, 521-535. https://doi.org/10.22358/jafs/67120/2005

23. Hrdinka C, Zollitsch W, Knaus W, Lettner F. Effect of dietary fatty acid pattern on melting point and composition of adipose tissue and intramuscular fat of broiler carcasses. Poultry. Sci. 1996; 75(2): 208-215. https://doi.org/10.3382/ps.0750208

24. Botsoglou NA, Govaris A, Botsoglou EN, Grigoropoulou SH, Papageorgiou G. Antioxidant activity of dietary oregano essential oil and alpha-tocopherol acetate supplementation in long term frozen stored turkey meat. J. Agric. Food Chem. 2003; 51(10): 2930-2936. DOI: 10.1021/jf021034o

25. Farag RS, Daw ZY, Abo-Raya SH. Influence of some spice essential oils on Aspergillus parasiticus growth and production of aflatoxins in a synthetic medium. J. Food Sci. 1989; 54(1): 74-76. DOI: 10.1111/j.13652621.1989.tb08571.x

26 Pereira CAM, Maia JF. Estudo da atividade antioxidante do extrato e do óleo essencial obtidos das folhas de alfavaca (Ocimum gratissimum L.). Cienc. Tecnol. Aliment. 2007; 27: 624-632. http://www.scielo.br/pdf/cta/v27n3/a30v27n3.pdf

27. Ozcan, MM, Erel O, Herken EE. Antioxidant activity, phenolic content, and peroxide value of essential oil and extracts of some medicinal and aromatic plants used as condiments and herbal teas in Turkey. J Med Food. 2009; 12(1): 198-202. http://online.liebertpub.com/toc/jmf/12/1

28. Scheuermann GN, Cunha Junior A, Cypriano I, Gabbi AM. Phytogenic Additive as an Alternative to Growth Promoters in Broiler Chickens. Ciencia Rural. 2009; 39: 2. http://dx.doi.org/10.1590/S0103$\underline{84782009000200032}$

29. Utiyama CE, Oetting LL, Giani PA, Ruiz US, Miyada VS. Efeitos de antimicrobianos, prebióticos, probióticos e extratos vegetais sobre a microbiota intestinal, a freqüência de diarréia e o desempenho de leitões recém-desmamados. R Bras Zootec. 2006; 35(6): 2359-2367. http://www.scielo.br/pdf/\%0D/rbz/v35n6/23.pdf 30. Barreto MSR, Menten JFM, Racanicci AMC, Pereira PWZ, Rizzo PV. Plant extracts used as growth promoters in broilers. Rev Bras Cienc Avic. 2008. 10(2): $109-115$ http://www.scielo.br/pdf/rbca/v10n2/06.pdf 